Article available at http://www.parasite-Journal.org or nttp://dx.dol.org/10.1051/parasite/199502s2211

\title{
ASCARIDOID NEMATODES OF TELEOSTEAN FISHES FROM THE EASTERN NORTH ATLANTIC AND SEAS OF THE NORTH OF EUROPE
}

\author{
PETTER A.J.* \& CABARET J.** \\ Technical collaboration : TCHEPRAKOFF R.*
}

\section{Summary :}

Ascarid parasites of Teleostean fishes from the North Eastern Atlantic and seas of the North of Europe deposited in the collections of the "Museum National d'Histoire Naturelle de Paris" are studied. The ratios oesophagus length/width of cervical alae and ventricular appendage length/width of cervical alae allow Hysterothylacium aduncum to be divided into two subspecies: $H$. aduncum aduncum was found in Alosa fallax, A. alosa, Belone belone, Psetta maxima, Lophius piscatorius, Trachurus trachurus, Merluccius merluccius and Trisopterus luscus whereas $H$. aduncum gadi was found in Pollachius pollachius, P. virens, Gadus morhua, Merlangus merlangus, Scomber scombrus and Salmo salar. Hysterothylacium cornutum, $H$. rigidum and Maricostula incurva are recorded respectively from Thunnus germo alalonga, Lophius piscatorius and Xiphias gladius. The following species are described: Hysterothylacium reliquens from Pagellus acarne and Microchirus azevia, Hysterothylacium sp. from Callionymus lyra and Goezia sp. from Trisopterus luscus. A key is presented for the species of Raphidascaridinae parasites of Teleostean fishes from North Eastern Atlantic and seas of the North of Europe.

KEY WORDS : nematoda. Ascaridoidea. teleostean fish. North Eastern Atlantic. seas of the North of Europe. systematics.

\section{INTRODUCTION}

1 he ascarid fauna of Teleostean fishes of North Eastern Atlantic and Seas of the North of Europe has been studied by many authors and is relatively well known. Excluding the species insufficiently described, seven species are known : Hysterothylacium aduncum, $H$. gadi, $H$. auctum, $H$. rigidum, H. cornutum, Maricostula incurva and Goezia sigalasi. However, the validities of Hysterothylacium gadi and H. auctum are under discussion, these species being considered as junior synonyms of $H$. aduncum by many authors.

\footnotetext{
* Laboratoire de Biologie Parasitaire, Protistologie, Helminthologie (CNRS UA 114), Museum National d'Histoire Naturelle, 61, rue Buffon, 75231 Paris Cedex 05, France.

** INRA, Centre de Recherches de Tours, Station de Pathologie aviaire et de Parasitologie, 37380 Nouzilly, France.

Correspondence : A.J. Petter, Tel : 33(1) 40793508 ; Fax : 33 (1) 40793499 .
}

Résumé : ASCARIDES PARASITES DE POISSONS TÉLÉOSTÉENS DE L'ATLANTIQUE NORD-ORIENTAL ET DES MERS DU NORD DE L'EUROPE

Les espèces d'Ascarides parasites de Poissons Téléostéens de l'Atlantique Nord-oriental et des mers du Nord de l'Europe présentes dans les collections du Museum National d'Histoire Naturelle de Paris sont étudiées. Les mesures relatives, longueur de l'oesophage/largeur des ailes cervicales et longueur de l'appendice oesophagien/largeur des ailes cervicales, permettent de distinguer deux sous-espèces chez Hysterothylacium aduncum : $\mathrm{H}$. aduncum aduncum est présente chez Alosa fallax, A. alosa, Belone belone, Psetta maxima, Lophius piscatorius, Trachurus trachurus, Merluccius merluccius et Trisopterus luscus; $\mathrm{H}$. aduncum gadi est présente chez Pollachius pollachius, P. virens, Gadus morhua, Merlangius merlangus, Scomber scombrus et Salmo salar. Hysterothylacium cornutum, $H$. rigidum et Maricostula incurva sont signalés respectivement chez Thunnus (Germo) alalunga, Lophius piscatorius et Xiphias gladius ; Hysterothylacium reliquens est redécrit chez Pagellus acarne et Microchirus azevia; Hysterothylacium sp. et Goezia sp. sont décrits respectivement chez Callionymus lyra et Trisopterus luscus. Une clef dichotomique des espèces de Raphidascaridinae parasites de Poissons Téléostéens de l'Atlantique Nord-oriental et des mers du Nord de l'Europe est donnée.

MOTS CLES : nematodes. Ascaridoidea. poissons téléostéens. Atlantique nordoriental. mers du nord de l'Europe. systématique.

This paper gives the results of the study of Ascarids from these seas deposited in the collections of the Museum National d'Histoire Naturelle de Paris (MNHN). A morphological and biometrical study was performed for specimens from various hosts and localities referred to Hysterothylacium aduncum and H. gadi, in order to discover if the two species could be distinguished. Six other species were present, including $H$. reliquens, which is recorded for the first time in the North Eastern Atlantic.

\section{MATERIALS AND METHODS}

pecimens had been initially fixed in formaldehyde or in $70 \%$ alcohol, and were preserved in $70 \%$ alcohol. The morphological study and measurements were made after clearing in lactophenol. Variations in measurements are caused by fixation and clearing methods (see Fagerholm, 1979; Fagerholm and Lövdahl, 1984) : for the biometrical 
analysis, we used the measured lengths without correction. All measurements are in $\mu$ m except the body length and distance anterior extremity-vulva, which are given in $\mathrm{mm}$.

\section{RESULTS}

\section{HYSTEROTHYLACIUM ADUNCUM (Rud., 1802)}

Some confusion exists concerning the systematics of the species Hysterothylacium aduncum (Rudolphi, 1802) and $H$. gadi (O.F. Müller, 1776) [= H. clavatum (Rudolphi, 1809)]. Rudolphi originally described in 1802 the species Ascaris adunca from Alosa alosa (L., 1756) (= Clupea alosa); Ascaris gadi was created by Müller in 1776, and synonymised by Rudolphi (1809) with his new species Ascaris clavata parasite of Trisopterus luscus (L., 1758) (= Gadus barbatus); the description of Müller being older, the name gadi must prevail. The descriptions of Müller and Rudolphi are very brief, but Rudolphi (1809) placed $A$. clavata in a group of species with an alate head ("capite alato") and $A$. adunca in a group with a bare head ("capite nudo"). Later, many authors seem to have assigned their specimens to one species or the other, by relying only on their hosts. Punt (1941) synonymised $H$. gadi with $H$. aduncum, and this was followed by Berland (1961), Petter (1969) and Fagerholm (1982). On the other hand, Dollfus (1953), in accordance with a personal communication from Baylis, questioned this synonymy and proposed an attempt of differentiation based on the shape of labial flanges and the width of cervical alae, and Hartwich (1975) considered the two species valid and gave descriptions and a key of differentiation based on the study of specimens from the "Berliner Zoologischen Museum".

According to Hartwich (1975), $H$. gadi differs from $H$. aduncum : - by having cervical alae becoming wide at the base of the lips, their maximum width reaching $140 \mu \mathrm{m}$, whereas in $H$. aduncum, cervical alae widen progressively, and their maximal width reaches only $50 \mu \mathrm{m}$; - by flanges of the dorsal lip less rounded; - by spicules measuring 5-8\% of body length, whereas in $H$. aduncum they measure more than $10 \%$ of body length; - by having one or two adanal pairs and six postanal pairs of papillae, whereas in $H$. aduncum only four to six pairs of single postanal papillae are present. Also according to Hartwich, H. gadi is chiefly a parasite of Gadiformes, but probably also of other carnivorous and of a few migratory fish, whereas $H$. aduncum is a parasite of Clupeiformes, but has also been recorded in other plankton and small prey eating fish.

\section{MATERIAL STUDiED}

Each lot includes specimens collected in one or several fish of the same species, at the same date and from the same locality.

Material used for the biometrical studies

86 worms ( 47 males and 39 females) were analysed, corresponding to the specimens on whom all measurements could be made. Numbers in square brackets are the serial numbers of specimens used in multivariate analyses.

Pollachius virens (L., 1758) (Gadidae, Gadiformes) : Lot $\mathrm{n}^{\circ} 1: 8$ o and $^{\circ} q \mathrm{n}^{\circ}$ MNHN $484 \mathrm{BB}$; western Scotland, Faroe islands; collected by V. Angot, April and September 1958 [o 1-8; ㅇ 1-7]. Lot $n^{\circ} 2: 2$ o and 3 o $n^{\circ}$ 1BF; Dublin (Ireland); collection R. Ph. Dollfus; 25-10-1937 [के 19-20; q 18-20]. Pollachius pollachius (L., 1758) : Lot $\mathrm{n}^{\circ} 3: 5$ o and $39 \mathrm{n}^{\circ} 2 \mathrm{BF}$; Concarneau (France); collection R. Ph. Dollfus; 3-7-1940 [o 21-25; ㅇ 21-23]. Lot $n^{\circ} 4: 1$ \& $n^{\circ} 701$ BB; Roscoff (France); collection R. Ph. Dollfus; 18-9-1913 [o 24]. Gadus morbua L., 1758 (Gadidae) : Lot $\mathrm{n}^{\circ} 8: 3$ o and 2 i $\mathrm{n}^{\circ} 3 \mathrm{BF}$; Dogger Bank (North Sea); collection R. Ph. Dollfus; October 1928 [o 26-28; + 25-26]. Merlangius merlangus (L., 1758) (Gadidae) : Lot $\mathrm{n}^{\circ} 11: 2$ o $\mathrm{n}^{\circ} 489 \mathrm{BB}$; North Sea; collected by de Panafieu; 1985 [ 0 3 38-39]. Merluccius merluccius (L., 1758) (Merluciidae, Gadiformes) : Lot $n^{\circ} 12: 2$ ot and 1 \& $n^{\circ} 687$ BB; Rabat (Morocco); collection R. Ph. Dollfus; January1954 [ 0 40-41; \& 33]. Lot $n^{\circ} 13$ : 28 and 2 i $\mathrm{n}^{\circ} 691 \mathrm{BB}$; Rabat; collection R. Ph. Dollfus; 29-3-1949 [ช 42-43; ㅇ 34-35]. Mullus surmuletus L., 1758 (Mullidae, Perciformes) : Lot $n^{\circ} 16: 1$ \& $n^{\circ} 707 \mathrm{BB}$; Concarneau; collection R. Ph. Dollfus; 23-6-1944 [o 36]. Lot $n^{\circ} 17: 1$ of and 3 o $n^{\circ} 708 \mathrm{BB}$; Concarneau; collection R. Ph. Dollfus; 18-6-1942 [o 44; ㅇ 37-39]. Lot $\mathrm{n}^{\circ} 18: 1$ o $\mathrm{n}^{\circ}$ 709 BB; Concarneau; collection R. Ph. Dollfus; 18-6-1943 [के 45]. Mullus barbatus L., 1758 : Lot $\mathrm{n}^{\circ} 20: 1$ के $\mathrm{n}^{\circ}$ 719BB; Rabat ; collection R. Ph. Dollfus; 30-9-1926 [o 46]. Lot $n^{\circ}$ 21: 1 o $\mathrm{n}^{\circ} 138 \mathrm{G}$; St Malo (France); collected by A. Coumbaras; 12-7-1962 [0 47]. Scomber scombrus L., 1758 (Scombridae, Perciformes) : Lot $\mathrm{n}^{\circ} 22: 4$ o and 3 $9 \mathrm{n}^{\circ} 7 \mathrm{BF}$; Concarneau; collection R. Ph. Dollfus; 26-6-1940 [ के 34-37; क 30-32]. Trachurus trachurus (L., 1758) (Carangidae, Perciformes) : Lot $\mathrm{n}^{\circ} 24: 2 \delta^{\circ}$ and 1 \& $\mathrm{n}^{\circ} 8 \mathrm{BF}$; Concarneau; collection R. Ph. Dollfus : 9-7-1941 [o 32-33; 우 29]. Lophius piscatorius L., 1758 (Lophiidae, Lophiiformes) : Lot $n^{\circ} 27: 3$ $\delta$ and 1 i n 468 Q; île d'Yeu (France); collected by A. J.

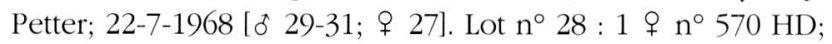
Concarneau; collection R. Ph. Dollfus; 22-6-1933 [q 28]. Alosa fallax (Lacépède, 1803) (Clupeidae, Clupeiformes) : Lot $n^{\circ} 35: 10$ o and 10 o n 511 BB; Morocco; collection R. Ph. Dollfus; 20-5-1951 [ơ 9-18; ㅇ 8-17].

\section{Other material}

Pollachius pollachius (L. 1758) : Lot $\mathrm{n}^{\circ} 5: 1$ o $\mathrm{n}^{\circ} 137$ BA; Roscoff; collected by A.J. Petter ; 17-7-1970. Trisopterus luscus (L., 1758) (Gadidae) : Lot n $6: 1$ o $\mathrm{n}^{\circ} 472$ Q; Le Croisic 
(France); collected by A.J. Petter; 22-7-1968. Lot $\mathrm{n}^{\circ} 7: 2 q$ $\mathrm{n}^{\circ} 663$ BB; Casablanca (Morocco); collection R. Ph. Dollfus; 24-4-1950. Gadus morbua L., 1758: Lot n $8: 1$ 우 3 BF; Dogger Bank (North Sea); collection R.Ph. Dollfus; October 1928. Merlangius merlangus (L., 1758) (Gadidae) : Lot $\mathrm{n}^{\circ} 9$ : 3 ㅇ n 526 BB; Concarneau; collection R. Ph. Dollfus; 18-61941. Lot $n^{\circ} 10: 1$ o $n^{\circ} 4 \mathrm{BF}$; Boulogne (France); collection R. Ph. Dollfus; 17-11-1955. Merluccius merluccius (L., 1758) (Merlucciidae, Gadiformes) : Lot $n^{\circ} 14: 1 \delta$ and 1 i $n^{\circ} 5$ BF; Concarneau; collection R. Ph. Dollfus; 2-7-1931. Lot $n^{\circ}$ 15: 1 o n 469 Q; Le Croisic; collected by A. J. Petter; 22-71968. Mullus surmuletus L., 1758 (Mullidae, Perciformes) : Lot $n^{\circ} 19: 1 q n^{\circ} 6$ BF; Bay of Biscay; collection R. Ph. Dollfus; June 1948. Mullus barbatus L., 1758 : Lot $n^{\circ} 20: 1$ 응 719 BB; Rabat; collection R. Ph. Dollfus; 30-9-1926. Lot $\mathrm{n}^{\circ} 21$ : 3 \& $\mathrm{n}^{\circ} 138 \mathrm{G}$; St Malo (France); collected by A. Coumbaras; 12-7-1962. Scomber scombrus L., 1758 (Scombridae, Perciformes) : Lot $n^{\circ} 23: 1 \delta$ and $1 \uparrow n^{\circ} 723$ BB; Stornoway (Hebrides isles); collection R. Ph. Dollfus; 18-7-1929. Psetta maxima (L. 1758) (Scophthalmidae, Pleuronectiformes) : Lot $n^{\circ} 25: 2$ n $n^{\circ} 497$ Q; Le Croisic; collected by A. J. Petter; 5-8-1968. Lot $n^{\circ} 26: 1$ ô $\mathrm{n}^{\circ} 9 \mathrm{BF}$; Concarneau; collection R. Ph. Dollfus; 18-6-1943. Zeus faber L., 1758 (Zeidae, Zeiformes) : Lot $\mathrm{n}^{\circ} 29: 4 q \mathrm{n}^{\circ} 10 \mathrm{BF}$; Concarneau; collection R. Ph. Dollfus; 2-9-1943. Lot $\mathrm{n}^{\circ} 30: 1$ $\delta$ and $1+n^{\circ} 11 \mathrm{BF}$; collection R. Ph. Dollfus; locality and date not mentioned. Lot $n^{\circ} 31: 1$ o and 2 q $n^{\circ} 716 \mathrm{BB}$; Concarneau; collection R. Ph. Dollfus; 14-5-1943. Lot $n^{\circ} 32$ : 2 的 12 BF; Morocco; collection R. Ph. Dollfus; 19-6-1966. Lot $\mathrm{n}^{\circ} 33: 1$ o $\mathrm{n}^{\circ} 13 \mathrm{BF}$; locality not mentioned; collection R. Ph. Dollfus; 1933. Belone belone (L., 1758) (Belonidae, Beloniformes) : Lot $n^{\circ} 34: 1$ i $n^{\circ} 710 \mathrm{BB}$, Concarneau; collection R. Ph. Dollfus; 28-4-1946. Alosa alosa (L., 1758) : Lot $\mathrm{n}^{\circ} 36$ : 1 o $\mathrm{n}^{\circ} 652 \mathrm{BB}$; Casablanca; collection R.Ph. Dollfus; 30-4-1953. Lot $n^{\circ} 37: 1$ q $n^{\circ} 528$ BB; Morocco; collection R. Ph. Dollfus; 9-9-1926. Salmo salar L., 1758 (Salmonidae, Clupeiformes) : Lot $\mathrm{n}^{\circ} 38: 2$ ㅇ $\mathrm{n}^{\circ} 726 \mathrm{BB}$; Concarneau; collection R. Ph. Dollfus; 18-6-1943.

\section{MORPHOLOGICAL STUDIES}

Detailed descriptions of the species were given by Punt (1941), Berland (1961) and Hartwich (1975), so it appeared unnecessary to give a complete description of the material studied, and we only discuss below the different characters which have been suggested to differentiate the two species.

\section{Cervical alae}

At first sight, two groups seem to be present, differing by the width of cervical alae : in the first group (Fig. 1A, F, J) the cervical alae are very wide in the oesophageal region, whereas in the second group, alae are hardly wider in the anterior region than in the middle and posterior ones (Fig. 2A, C, J). However, this character is not sufficient to differentiate the species, as all intermediaries exist between wide and narrow alae and whatever width might be chosen to differentiate the two groups, in some lots the range of width overlaps those of the two groups. Independently of their width, in most specimens the cervical alae are wide from their beginning and the figure of the anterior extremity of Hysterothylacium gadi given by Hartwich actually corresponds to the specimens with narrow cervical alae (Fig. 2C).

\section{Shape of lips}

We did not find any difference in the shape of the labial flanges between the two putative groups; individual variations in this shape were observed, independent of the width of cervical alae (Fig. 1D, E Fig. 2C, D).

Caudal papillae (Fig. 1L, M, N, O - Fig. 2L, M, N, O, Fig. 3A, B, C)

No difference in the number and disposition of caudal papillae could be found. We observed in the two groups : - two subventral rows of precloacal papillae; the 10 to 12 posterior ones are small and close together; their number varies from 22 to 32 pairs in the specimens examined (Fig. 1L, Fig. 2L); the most posterior or the two posterior pairs may be adcloacal (Fig. 1N) - one precloacal medioventral papilla; seven or eight postcloacal pairs including : - five subventral pairs with third pair from the cloaca doubled; the most anterior or the two anterior pairs may be adcloacal (Fig. 1O, Fig. 2O); one papilla may be lacking on one side Fig. 2O, Fig. 3C); - one lateral pair corresponding to phasmids; - one subdorsal pair, often invisible in ventral view; - a second lateral pair can be seen in some juvenile specimens (Fig. 3A, B).

Spicules (Fig. 1P - Fig. 2P)

The shape of spicules is the same in all specimens ; their length in relation to body length varies between the lots, but there is no evident correlation between this length and the width of cervical alae; the length ranges observed in each group are different from those given by Hartwich for $H$. gadi and $H$. aduncum.

Therefore, the morphological analysis does not allow a separation into two species; however, the biometrical analysis given below shows that two morphological entities exist.

\section{BIOMETRICAL STUDIES}

Data analysis

The following multivariate analyses were used : principal component analysis (PCA) and clustering analyses based on unweighted arithmetic average (UPGMA) in order to identify putative groups, discriminant analysis to identify the most interesting variables, and finally segmentation based on Chi- 


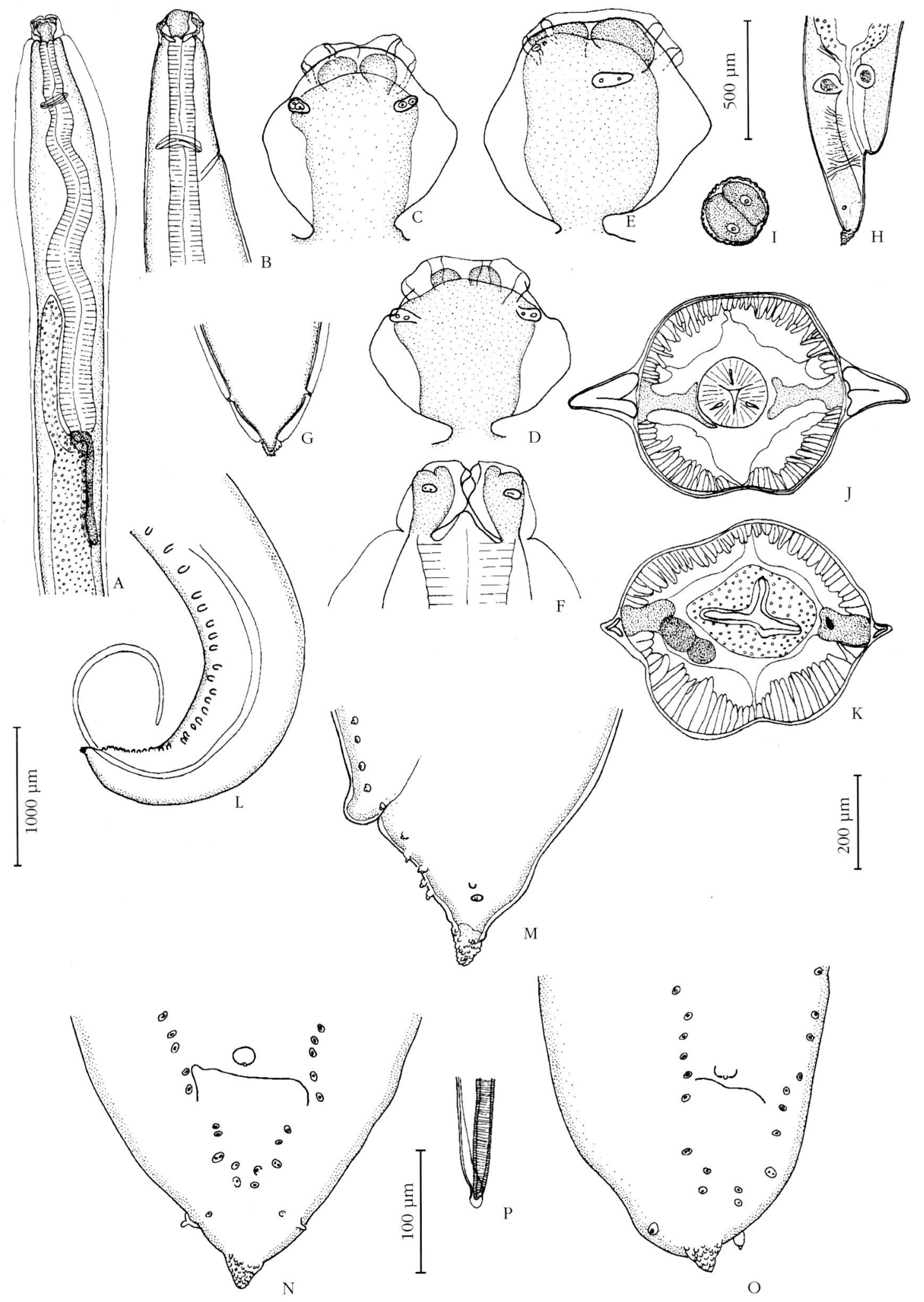

Fig. 1. - Hysterothylacium aduncum gadi (O.F. Müller, 1776, species), specimens parasitizing Pollachius virens (lot $\mathrm{n}^{\circ} 1$ ). A, anterior part, median view ; B, anterior part, lateral view ; C,D, dorsal lips ; E, latero-ventral lip ; F, female, anterior end, lateral view ; G, female, posterior end, ventral view ; H, female, posterior end, lateral view ; I, egg ; J, cross-section at level of oesophagus ; $\mathrm{K}$, cross-section at level of ventricular appendage ; L, male, posterior part, lateral view ; M, male, posterior end, lateral view ; N,O, males, posterior ends, ventral views ; P, spicule, distal end. Scale lines $(\mu \mathrm{m}): \mathrm{A}, \mathrm{B}, \mathrm{L}$, 1000 ; C,D,E,I,M,N,O,P, $100 ;$ H, 500 ; F,G,J,K, 200. 


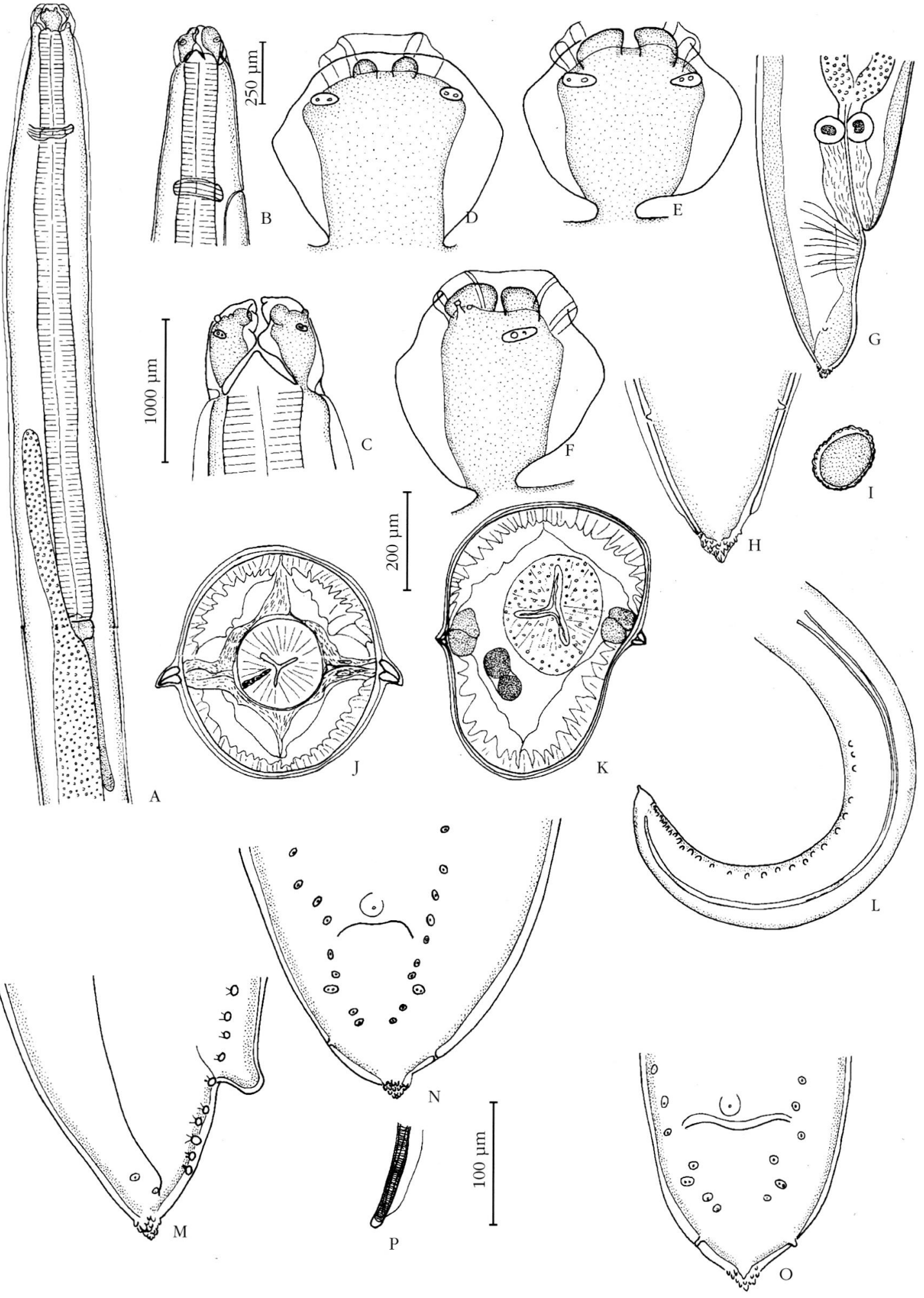

Fig. 2. - Hysterothylacium aduncum aduncum (Rud., 1802), specimens parasitizing Alosa fallax (lot $\mathrm{n}^{\circ} 35$ ). A, anterior part, median view ; B, anterior part, lateral view ; C, anterior end, lateral view ; D,E, dorsal lips ; F, latero-ventral lip ; G, female, posterior end, lateral view ; $\mathrm{H}$, female, posterior end, ventral view ; I, egg ; J, cross-section at level of oesophagus; $\mathrm{K}$, cross-section at level of ventricular appendage ; $\mathrm{L}$, male, posterior part, lateral view ; $\mathrm{M}$, male, posterior end, lateral view; N,O, males, posterior ends, ventral views ; P, spicule, distal end. Scale lines ( $\mu \mathrm{m})$ : A,L, $1000 ; \mathrm{B}, 250 ; \mathrm{C}, \mathrm{G}, \mathrm{J}, \mathrm{K}$, 200; D,E,F,H,I,M,N,O,P, 100. 


\begin{tabular}{|c|c|c|c|c|c|c|c|c|}
\hline Host & lot & erial $n^{\circ}$ & 1 & $\mathrm{~L}$ & s & $\mathrm{o}$ & a & c \\
\hline \multirow[t]{8}{*}{$P$. virens } & 1 & 1 & 29 & 110 & 3200 & 2600 & 700 & 850 \\
\hline & & 2 & 31 & 120 & 4000 & 2750 & 600 & 1180 \\
\hline & & 3 & 34 & 150 & 3650 & 2140 & 600 & 850 \\
\hline & & 4 & 36 & 95 & 3100 & 2850 & 775 & 1050 \\
\hline & & 5 & 38 & 80 & 3000 & 2825 & 675 & 1050 \\
\hline & & 6 & 39 & 125 & 3550 & 3325 & 850 & 1400 \\
\hline & & 7 & 39 & 120 & 4000 & 3100 & 800 & 1250 \\
\hline & & 8 & 41 & 115 & 3125 & 2750 & 700 & 1250 \\
\hline \multirow[t]{10}{*}{ A. fallax } & 5 & 9 & 21 & 30 & 3000 & 2940 & 720 & 1075 \\
\hline & & 10 & 22 & 20 & 3380 & 2700 & 680 & 1150 \\
\hline & & 11 & 23 & 30 & 3820 & 2150 & 700 & 800 \\
\hline & & 12 & 29 & 30 & 3715 & 2900 & 900 & 970 \\
\hline & & 13 & 29 & 30 & 3645 & 3150 & 940 & 1040 \\
\hline & & 14 & 31 & 30 & 3575 & 3100 & 850 & 900 \\
\hline & & 15 & 32 & 40 & 3385 & 3400 & 1070 & 1440 \\
\hline & & 16 & 33 & 35 & 3735 & 2860 & 850 & 1000 \\
\hline & & 17 & 34 & 20 & 4425 & 3460 & 1025 & 1400 \\
\hline & & 18 & 35 & 50 & 3335 & 3300 & 980 & 1300 \\
\hline \multirow[t]{2}{*}{$P$. virens } & 2 & 19 & 37 & 90 & 2300 & 3650 & 1275 & 1250 \\
\hline & & 20 & 45 & 100 & 1850 & 3150 & 850 & 1100 \\
\hline \multirow[t]{5}{*}{ P. pollachius } & 3 & 21 & 16 & 50 & 1300 & 1880 & 430 & 700 \\
\hline & & 22 & 15 & 40 & 1100 & 1400 & 360 & 460 \\
\hline & & 23 & 19 & 50 & 1100 & 2000 & 460 & 650 \\
\hline & & 24 & 44 & 75 & 2560 & 3200 & 850 & 1300 \\
\hline & & 25 & 26 & 85 & 1800 & 1850 & 630 & 850 \\
\hline \multirow[t]{3}{*}{ G. morbua } & 8 & 26 & 58 & 120 & 2160 & 4300 & 1060 & 1525 \\
\hline & & 27 & 56 & 60 & 3250 & 4050 & 1120 & 1200 \\
\hline & & 28 & 40 & 60 & 2400 & 2800 & 760 & 1000 \\
\hline \multirow[t]{3}{*}{ L. piscatorius } & 27 & 29 & 41 & 30 & 1800 & 2850 & 950 & 600 \\
\hline & & 30 & 30 & 35 & 1500 & 2800 & 810 & 1200 \\
\hline & & 31 & 25 & 35 & 1560 & 2650 & 900 & 1300 \\
\hline \multirow[t]{2}{*}{ T. trachurus } & 24 & 32 & 29 & 50 & 1330 & 2700 & 1000 & 1050 \\
\hline & & 33 & 36 & 45 & 1800 & 3450 & 1100 & 1130 \\
\hline \multirow[t]{4}{*}{ S. scombrus } & 22 & 34 & 33 & 90 & 1770 & 2600 & 1120 & 950 \\
\hline & & 35 & 31 & 70 & 2000 & 2550 & 920 & 1020 \\
\hline & & 36 & 29 & 80 & 1250 & 3150 & 1150 & 1450 \\
\hline & & 37 & 27 & 70 & 1500 & 2450 & 900 & 900 \\
\hline \multirow[t]{2}{*}{ M. merlangius } & 11 & 38 & 20 & 55 & 980 & 1800 & 600 & 580 \\
\hline & & 39 & 17 & 40 & 1260 & 1400 & 430 & 225 \\
\hline \multirow[t]{4}{*}{ M. merluccius } & 12 & 40 & 14 & 30 & 850 & 1920 & 500 & 600 \\
\hline & & 41 & 25 & 30 & 2100 & 2350 & 850 & 800 \\
\hline & 13 & 42 & 24 & 30 & 1570 & 2000 & 900 & 650 \\
\hline & & 43 & 23 & 30 & 1150 & 2100 & 850 & 850 \\
\hline \multirow[t]{2}{*}{ M. surmuletus } & 17 & 44 & 29 & 70 & 2200 & 3525 & 1060 & 940 \\
\hline & 18 & 45 & 47 & 60 & 2170 & 4950 & 1450 & 1700 \\
\hline \multirow[t]{2}{*}{ M. barbatus } & 20 & 46 & 52 & 50 & 3750 & 4500 & 1860 & 1800 \\
\hline & 21 & 47 & 44 & 65 & 2400 & 4200 & 1100 & 1600 \\
\hline
\end{tabular}

Table I. - Hysterothylacium aduncum : measurements of males analysed for the biometrical study.

\begin{tabular}{|c|c|c|c|c|c|c|c|}
\hline Host & lot & serial $n^{\circ}$ & 1 & $\mathrm{~L}$ & o & a & c \\
\hline \multirow[t]{7}{*}{$P$. virens } & 1 & 1 & 32 & 75 & 2500 & 600 & 1100 \\
\hline & & 2 & 36 & 85 & 3100 & 775 & 1550 \\
\hline & & 3 & 46 & 120 & 3600 & 700 & 1600 \\
\hline & & 4 & 46 & 125 & 3620 & 600 & 1600 \\
\hline & & 5 & 49 & 130 & 3950 & 850 & 1525 \\
\hline & & 6 & 51 & 130 & 3800 & 1000 & 1400 \\
\hline & & 7 & 51 & 125 & 4700 & 950 & 1500 \\
\hline \multirow[t]{10}{*}{ A. fallax } & 5 & 8 & 33 & 30 & 3475 & 680 & 1400 \\
\hline & & 9 & 35 & 30 & 3480 & 900 & 950 \\
\hline & & 10 & 36 & 30 & 3650 & 850 & 1260 \\
\hline & & 11 & 37 & 40 & 3600 & 950 & 1340 \\
\hline & & 12 & 37 & 35 & 4070 & 1000 & 1300 \\
\hline & & 13 & 38 & 40 & 3850 & 910 & 1350 \\
\hline & & 14 & 39 & 40 & 4235 & 1140 & 1340 \\
\hline & & 15 & 39 & 45 & 3900 & 1000 & 1250 \\
\hline & & 16 & 40 & 40 & 4600 & 1320 & 1600 \\
\hline & & 17 & 41 & 40 & 4650 & 1100 & 1750 \\
\hline \multirow[t]{3}{*}{$P$. virens } & 2 & 18 & 56 & 100 & 4050 & 950 & 1450 \\
\hline & & 19 & 49 & 90 & 3790 & 940 & 1350 \\
\hline & & 20 & 68 & 120 & 4770 & 900 & 2200 \\
\hline \multirow[t]{4}{*}{ P.pollachius } & 3 & 21 & 45 & 85 & 3400 & 725 & 1150 \\
\hline & & 22 & 53 & 100 & 3900 & 775 & 800 \\
\hline & & 23 & 45 & 90 & 3200 & 850 & 1160 \\
\hline & 4 & 24 & 45 & 80 & 3600 & 950 & 1500 \\
\hline \multirow[t]{2}{*}{ G. morbua } & 8 & 25 & 69 & 80 & 4100 & 960 & 1600 \\
\hline & & 26 & 67 & 110 & 3700 & 1350 & 2420 \\
\hline \multirow[t]{2}{*}{ L. piscatorius } & 27 & 27 & 39 & 40 & 2880 & 850 & 1000 \\
\hline & 28 & 28 & 33 & 60 & 3400 & 1050 & 1350 \\
\hline T. trachurus & 24 & 29 & 46 & 40 & 4610 & 1050 & 1075 \\
\hline \multirow[t]{3}{*}{ S. scombrus } & 22 & 30 & 39 & 90 & 3080 & 1100 & 1250 \\
\hline & & 31 & 38 & 110 & 2900 & 850 & 1100 \\
\hline & & 32 & 38 & 70 & 2800 & 900 & 950 \\
\hline \multirow[t]{3}{*}{ M. merluccius } & 12 & 33 & 23 & 40 & 2350 & 700 & 800 \\
\hline & 13 & 34 & 20 & 25 & 2225 & 800 & 950 \\
\hline & & 35 & 15 & 20 & 1460 & 580 & 600 \\
\hline \multirow[t]{4}{*}{ M. surmuletus } & 16 & 36 & 62 & 60 & 5450 & 1200 & 1875 \\
\hline & 17 & 37 & 65 & 65 & 5100 & 1000 & 1640 \\
\hline & & 38 & 73 & 70 & 6550 & 1400 & 2060 \\
\hline & & 39 & 83 & 100 & 6450 & 1200 & 2100 \\
\hline
\end{tabular}

Table II. - Hysterothylacium aduncum : measurements of females analysed for the biometrical study .

a : ventricular appendage length $(\mu \mathrm{m}) ; \mathrm{c}$ : intestinal caecum length $(\mu \mathrm{m}) ; 1$ : body length $(\mathrm{mm}) ; \mathrm{L}$ : width of cervical alae $(\mu \mathrm{m})$; $\mathrm{O}$ : oesophagus length $(\mu \mathrm{m}) ; \mathrm{s}$ : spicules length $(\mu \mathrm{m})$. 
square in order to find easy criterion for identification. The analyses were performed with a Stat-Ictf (1988) statistical computer package and interpreted according to Dagnelie (1975).

The data matrix was constituted with five measures for each female worm and by six measures for each male worm. The measures were : cervical alae (L), body length (1), oesophagus length (o), ventricular appendage (a), intestinal caecum (c), and additionally spicule length for males (s) [ tables I (males) and II (females)].

Results

The different measures were significantly linked $(\mathrm{P}<0,01)$. Among males, width of cervical alae and body length, length of spicules and body length, oesophagus and intestinal caecum lengths, ventricular appendage and intestinal caecum lengths. The worms harboured by Pollachius virens were very different from others, on second axis, whereas first axis did not allow differentiation between groups. Two groups (in males and females) were distinguished by means of cluster analysis based on relative values of parameters (actual value/width of cervical alae). The measures of the two putative groups (gadi versus aduncum) are shown in table III. The use of discriminant analysis did allow identification of the two groups : $100 \%$ of the worms were successfully classified into gadi and aduncum. Pseudo-F was 122 whereas highest $\mathrm{F}$ value was 118 for ventricular appendage in male worms. Pseudo-F was 235 and highest $\mathrm{F}$ value 190 for oesophagus in female worms. The advantage of multivariate analysis was reduced for males (pseudo-F and $\mathrm{F}$ values were similar) but was clear for female identification. Segmentation analysis based on two most important parameters (lengths of oesophagus and ventricular appendage) did show that two groups were significantly distinct $(\mathrm{P}<0,01)$, either in male or female worms (results shown in Figs. 4 and 5). Both measures were useful in identification (Chi-square of respectively 70.7 and 70.4 for 86 specimens). Group 1 (gadi) was characterized with $\mathrm{a} / \mathrm{L}<15$ and $\mathrm{o} / \mathrm{L}<54$ and group 2 (aduncum) was characterized with $\mathrm{a} / \mathrm{L}>15$ and $\mathrm{o} / \mathrm{L}>54$.

Those identification criteria were tested on 39 additional specimens (Fig. 6). Eight specimens (four parasites of Zeus faber, two of Mullus surmuletus, one of Trisopterus luscus and one of Merluccius merluccius) could not be classified, as the two parameters placed them in different groups. All specimens from the same lot and all the lots from the same host species belonged to the same group, except in four host species the specimens of which were distributed as follows : Gadus morhua : six specimens studied : four in group 1, two in group 2 (lot $\left.n^{\circ} 8\right)$. Zeus faber: 12 specimens studied : six in group 1 (in lots $n^{\circ} 29$ and 31), two in group 2 (in lots $n^{\circ} 29$ and 30), four could not be classified (in lots 30, 32 and 33). Mullus surmuletus: seven specimens studied : one in group 1 (in lot $\mathrm{n}^{\circ}$ 17), four in group 2 (in lots $n^{\circ} 16,17$ and 18), two could not be classified (in lots $n^{\circ} 17$ and 19). Mullus barbatus : six specimens studied : two in group 1 (in lot $n^{\circ} 21$ ), four in group 2 (in lots $n^{\circ} 20$ and 21).

\section{CONCLUSIONS}

The preceding data allowed a differentiation into two groups, which in the majority of cases were isolated, probably because of ecological rather than geographical reasons. In four hosts only, these two groups cohabited and in two of these four hosts (Zeus faber, Mullus surmuletus), intermediary forms were found, which, according to our interpretation, are crossbreeds. In the present state of knowledge, we therefore propose to consider these groups as two subspecies of Hysterothylacium aduncum.

The subspecies gadi was found chiefly in Gadiformes (Pollachius virens, P. pollachius, Gadus morbua, Merlangius merlangus), but also in one Perciform (Scomber scombrus) and one Clupeiform (Salmo salar); the subspecies aduncum in Clupeiformes (Alosa fallax, A. alosa), Beloniformes (Belone belone), Pleuronectiformes (Psetta maxima), Lophiiformes (Lophius piscatorius), Perciformes (Trachurus trachurus), but also in Gadiformes (Merluccius merluccius, Trisopterus luscus).

In most lots, the fishing places were not known. Only the harbours of arrival of boats were recorded. Nevertheless, we may conclude that fishes parasitised by the subspecies gadi have a geographical range not extending southwards beyond the European coasts, while the geographical range of the subspecies aduncum extends more southwards. These results are in agreement with the observations of Hartwich (1975).

\begin{tabular}{|c|c|c|c|c|c|}
\hline \multirow{3}{*}{ males } & \multirow[b]{2}{*}{$\mathrm{s} / \mathrm{L}$} & \multicolumn{2}{|c|}{ H. a. gadi } & \multicolumn{2}{|c|}{ H. a. aduncum } \\
\hline & & 27.3 & (6.4) & 87.7 & (45.6) \\
\hline & $\mathrm{O} / \mathrm{L}$ & 36.1 & (11.9) & 89.9 & (25.1) \\
\hline & $\mathrm{a} / \mathrm{L}$ & 10.5 & (3.9) & 28.2 & (6.9) \\
\hline & $\mathrm{c} / \mathrm{L}$ & 13.0 & (4.3) & 32.7 & (11.7) \\
\hline & 1/L & 409.7 & (112.1) & 928.5 & $(237.8)$ \\
\hline \multirow[t]{4}{*}{ females } & $\mathrm{O} / \mathrm{L}$ & 36.7 & (9.9) & 99.5 & (16.3) \\
\hline & $\mathrm{a} / \mathrm{L}$ & 9.8 & $(3.2)$ & 25.4 & $(4.7)$ \\
\hline & $\mathrm{c} / \mathrm{L}$ & 15.0 & (3.7) & 33.8 & (6.3) \\
\hline & 1/L & 514.5 & (131.2) & 1000.9 & $(118.0)$ \\
\hline
\end{tabular}

Table III. - Hysterothylacium aduncum : Relative values of parameters of the two subspecies distinguished by means of cluster analysis (means, standard deviations in brackets). a : ventricular appendage length $(\mu \mathrm{m}) ; \mathrm{c}$ : intestinal caecum length $(\mu \mathrm{m}) ; 1$ : body length $(\mu \mathrm{m}) ; \mathrm{L}$ : width of cervical alae $(\mu \mathrm{m}) ; \mathrm{o}$ : oesophagus length $(\mu \mathrm{m}) ; \mathrm{s}$ : spicules length $(\mu \mathrm{m})$. 

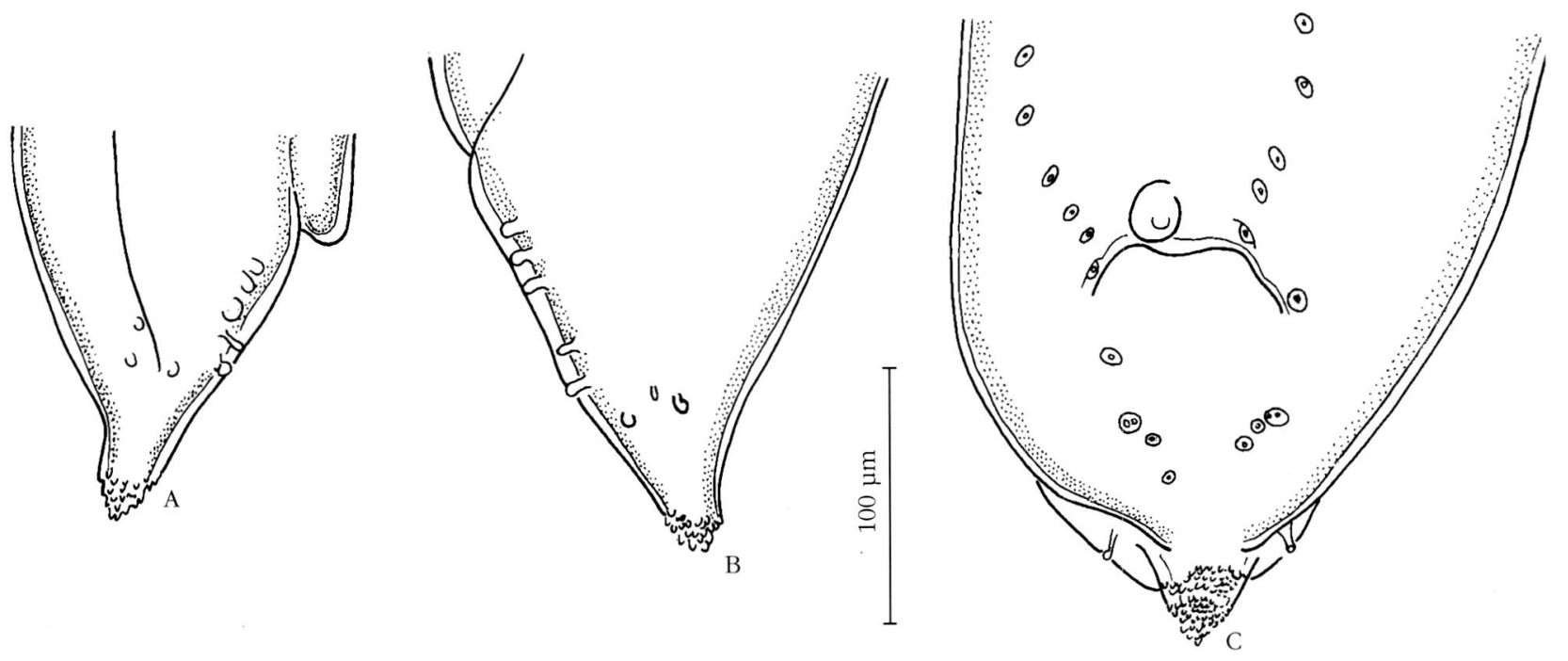

Fig. 3. - Male posterior ends. A, Hysterothylacium aduncum gadi, juvenile male parasitizing Scomber scombrus (lot $\mathrm{n}^{\circ} 22$ ), lateral view; B, Hysterothylacium aduncum aduncum, juvenile male parasitizing Trachurus trachurus (lot $\mathrm{n}^{\circ} 24$ ), lateral view; C, Hysterothylacium aduncum aduncum, male parasitizing Lophius piscatorius (lot $\mathrm{n}^{\circ} 27$ ), ventral view.

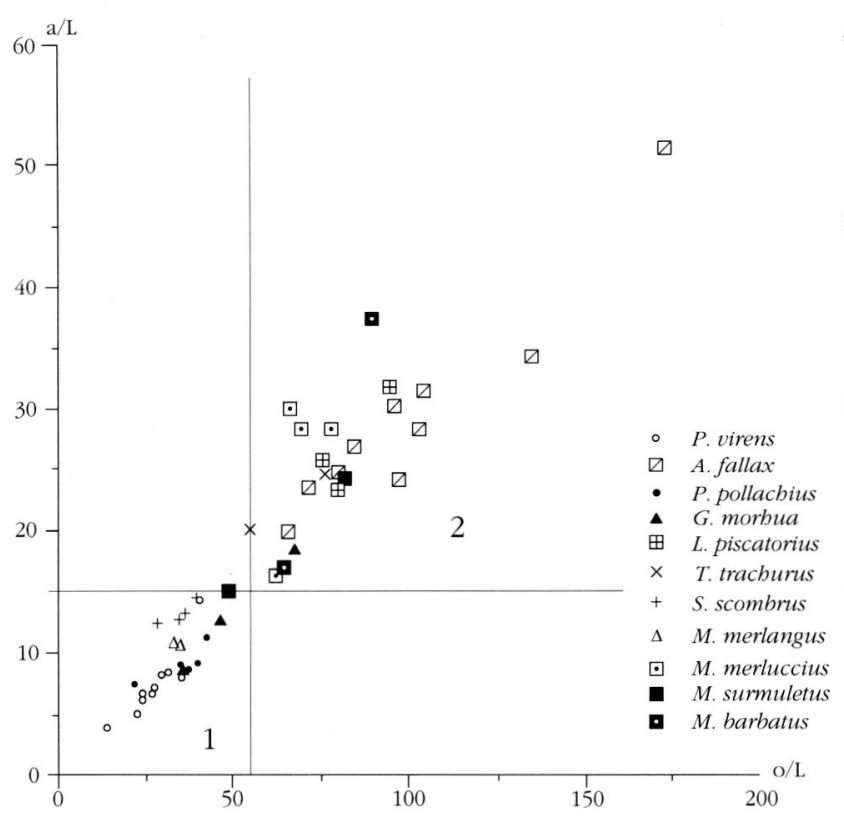

Fig. 4. - Hysterothylacium aduncum. Distribution of males in relation to parameters o/L (oesophagus length/width of cervical alae) and $\mathrm{a} / \mathrm{L}$ (ventricular appendage length/width of cervical alae) in 11 fish species. Groups 1 (gadi) and 2 (aduncum) are significantly distinct according to segmentation analysis.

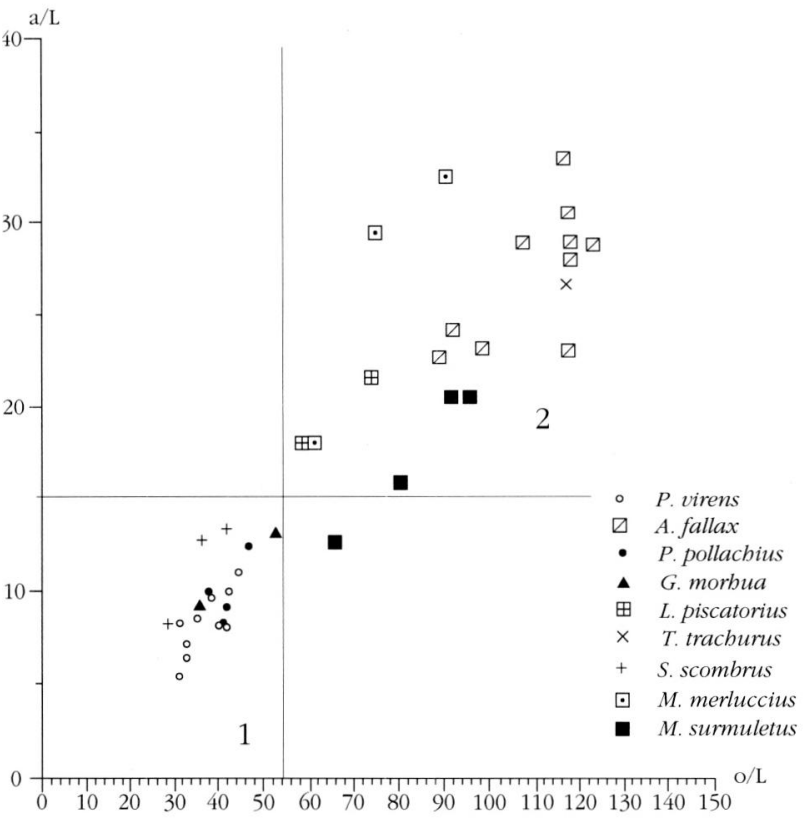

Fig. 5. - Hysterothylacium aduncum. Distribution of females in relation to parameters $\mathrm{O} / \mathrm{L}$ and $\mathrm{a} / \mathrm{L}$ in 9 fish species. Groups 1 (gadi) and 2 (aduncum) are significantly distinct according to segmentation analysis. 


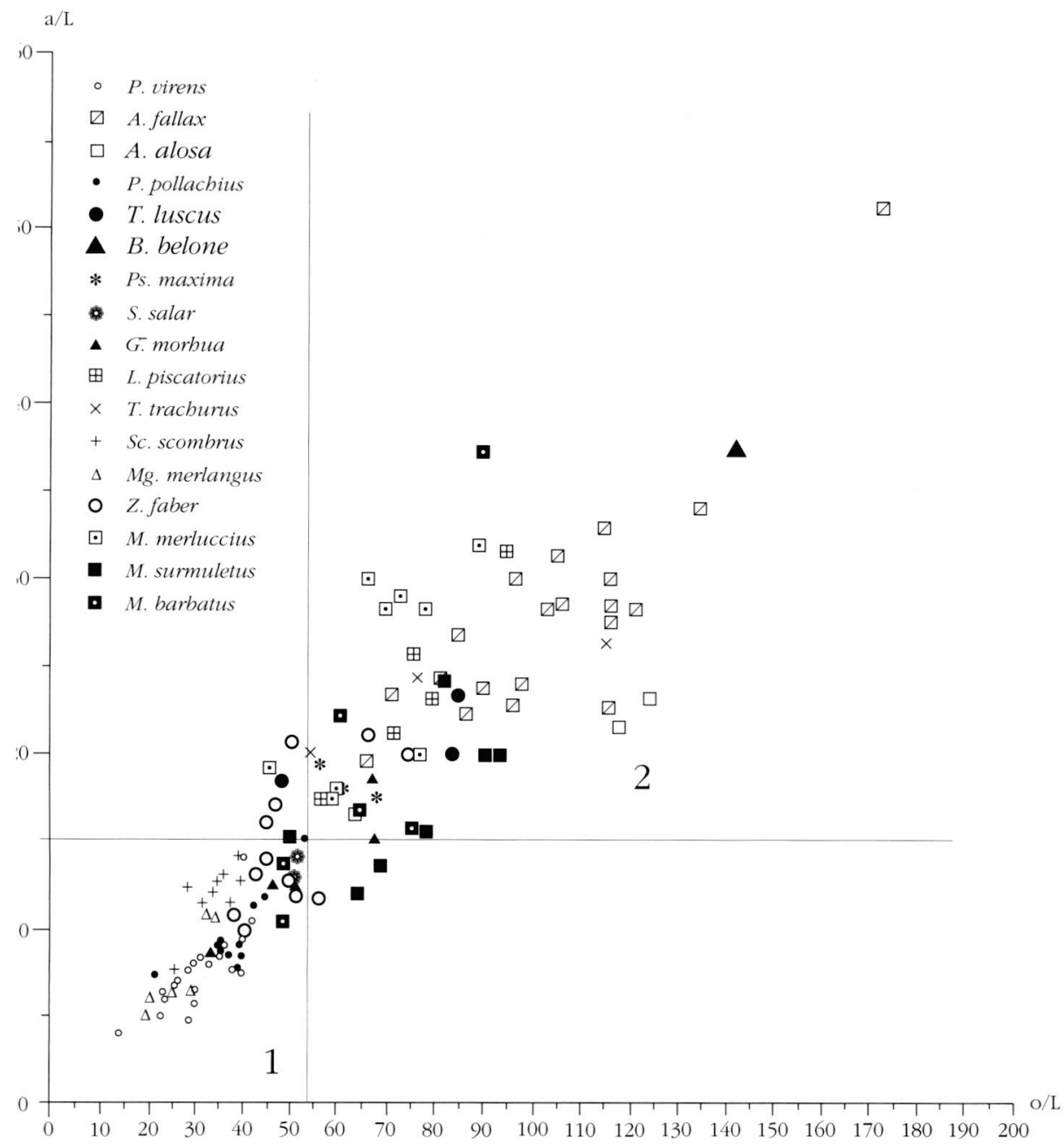

Fig. 6. - Hysterothylacium aduncum. Distribution of male and female specimens in relation to parameters $\mathrm{o} / \mathrm{L}$ et $\mathrm{a} / \mathrm{L}$ in 17 fish species. 1: sub-species gadi; 2 : sub-species aduncum.

\section{HYSTEROTHYLACIUM RELIQUENS}

(Norris and Overstreet, 1975) Fig. 7

Material : 3 of and 12 n ${ }^{\circ}$ MNHN $675 \mathrm{BB}, 486 \mathrm{BC}$, 537 BC; host : Pagellus acarne (Risso, 1826) (Sparidae); Morocco; 21-6-1957 and 18-4-1968. 1 of $\mathrm{n}^{\circ}$ MNHN 669 BB; host : Microcheirus azevia (Capello, 1867) (Soleidae); Morocco. Collection R.Ph. Dollfus.

\section{DESCRIPTION}

Body thinner anteriorly. Lateral alae very thin (5$10 \mu \mathrm{m})$, with supports V-shaped in cross-section, originating from the base of the lips and extending all along the body. Dorsal lip slightly wider than long, latero-ventral lips longer than wide. Lips lacking posterior lobes. Labial flanges constricted at middle of lips. Interlabia very short, not more than $1 / 4$ of lip length. Oesophagus 8.5-14.7\% of body length, ventricular appendage very thin, ratio oesophagus/ventricular appendage 1.8-3.9, intestinal caecum short, ratio oesophagus/caecum 3.6-7.9. Excretory pore at level of nerve ring. Tail with spined conical mucronate extremity.
Male : Spicules $4.9-7 \%$ of body length. About 27 pairs of preanal papillae, the ten most posterior pairs very close together; one big large medio-ventral preanal papilla; 5-7 postcloacal pairs (including phasmids) : one or two lateral and four or five ventro-laterals; second or third pair from the cloaca doubled.

Female : vulva without salient lips, slightly posterior to anterior third of body.

Measurements (range, means in parentheses) :

Females, $\mathrm{n}=7$ : length 18-75 (36.6); oesophagus 2350-8000 (4124.3); caecum 500-1100 (671); ventricular appendage 1100-2050 (1495); tail 300-650 (457.5). Males, $\mathrm{n}=4$ : length 14-43 (24.1); oesophagus 20603650 (2687.5); caecum 260-680 (425); ventricular appendage 1080-2000 (1407.5); tail 190-200 (196.6) ; spicules 720-2160 (1371.2).

\section{DisCUSSION}

Measurements and morphology of these specimens, especially the shape of lips, agree with those of $H$. reliquens, given by Norris and Overstreet, 1975 and Deardorff and Overstreet, 1980. H. reliquens has been 


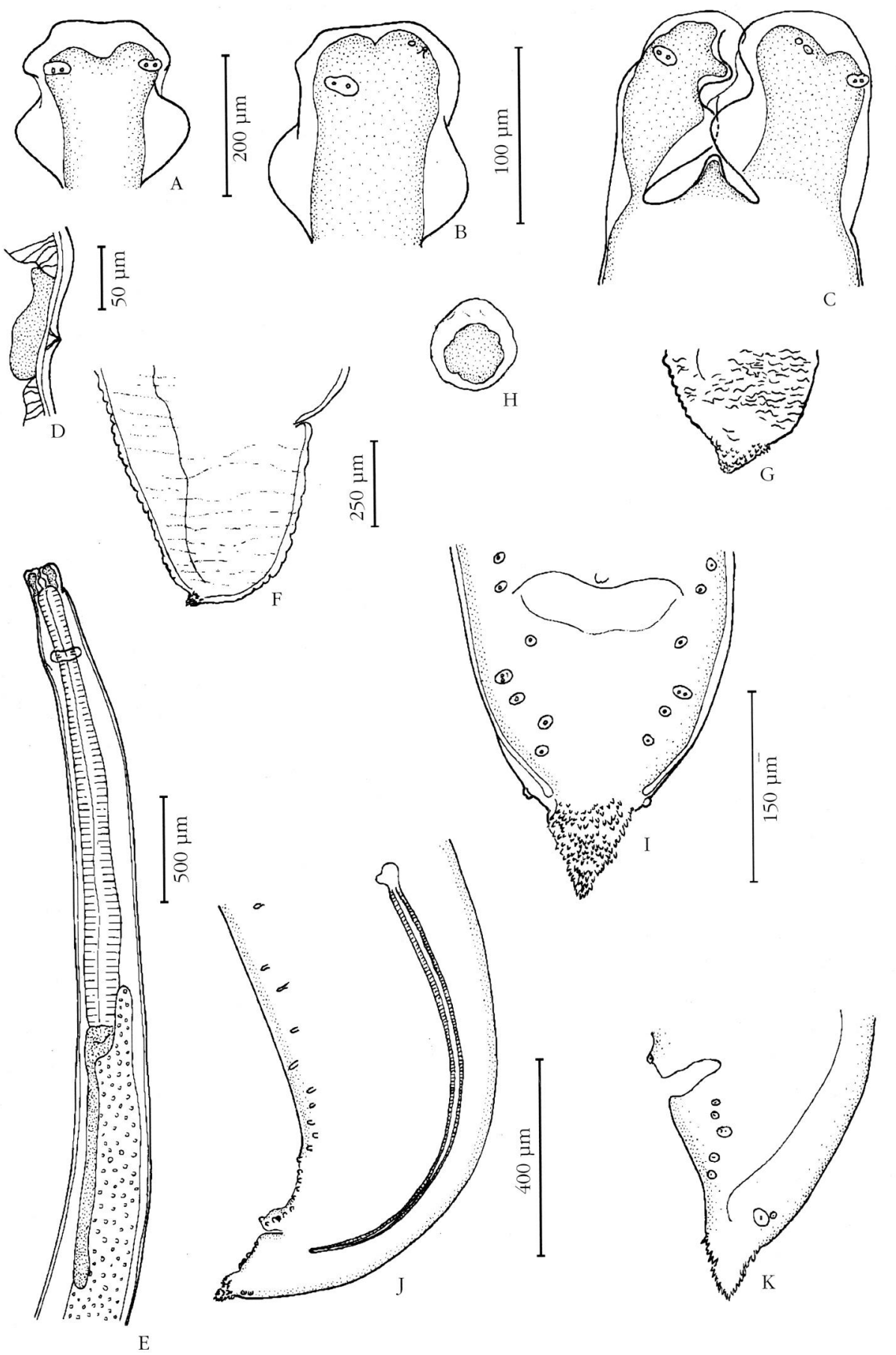

Fig. 7. - Hysterothylacium reliquens (Norris and Overstreet, 1975). A, dorsal lip; B, latero-ventral lip; C, anterior end, lateral view; D, cross-section of lateral ala at level of the anterior part of oesophagus; E, male, anterior part, lateral view; F, G, female, posterior ends; $\mathrm{H}$, egg; I, male, posterior end, ventral view; $\mathrm{J}$, male, posterior part, lateral view ; $\mathrm{K}$, male, posterior end, lateral view. Scale lines ( $\mu \mathrm{m})$ : A,C,G, 200; D, 50; B,H, : 100; E, 500; F, 250; J, 400; K, 150. 
reported from a Sparidae (Archosargus probatocephalus) (type-host) and other hosts in the Gulf of Mexico, Western North Atlantic and Pacific, but is recorded for the first time from Eastern North Atlantic.

\section{HYSTEROTHYLACIUM CORNUTUM}

(Stossich, 1904)

Material : several of and $q \mathrm{n}^{\circ} \mathrm{MNHN} 568 \mathrm{HD}$ and 455 BB, Concarneau, 1931-1937, 1947; collection R.Ph. Dollfus. 1 o and 1 o n MNHN 517 Q, Le Croisic, 108-1968; collected by A.J. Petter. Host : Thunnus (Germo) alalunga (Scombridae).

A part of the material from Concarneau was described by Dollfus, as Thynnascaris legendrei (n. gen. n. sp.), a species synonymised with T. cornutum by Berland (1961). Specimens from Le Croisic were studied by Petter (1969). The species is otherwise well known by the descriptions of Hartwich (1975), Deardorff and Overstreet (1982) and Bruce and Cannon (1989).

HYSTEROTHYLACIUM RIGIDUM (Rudolphi, 1809) Fig. 9H

Material : 6 o and 5 o , $\mathrm{n}^{\circ}$ MNHN $704 \mathrm{BB}$ and 540 BC, Concarneau, 1-2-1943 and 20-2-1946; collection R.Ph. Dollfus. 2 \& , 2 o and 4 anterior extremities, $n^{\circ}$ MNHN 488 Q, 637 Q, 653 Q and 696 Q, Le Croisic, 22-7-1968, 11-7-1969 and 26-7-1969; collected by A.J. Petter. Host : Lophius piscatorius L., 1758 (Lophiidae). A part of this material was studied by Petter (1969) and the species was well described by Hartwich (1975). Contrary to the observations of Petter (1969), the two components of the ventricular appendage appear unequal in cross-section in the anterior part of the appendage, as in $H$. aduncum; therefore, this character cannot be used to differentiate the crosssections of the two species.

\section{HYSTEROTHYLACIUM SP. Fig. 8}

Material : 2 +1 mature and 1 juvenile $\delta, n^{\circ}$ MNHN 538 BC; host : Callionymus lyra L., 1758 (Callionymidae); La Rochelle (France); May 1941; collected by J. Cadenat.

\section{DESCRIPTION}

Body thinner anteriorly. In the females and the mature male, very thin $(3-5 \mu \mathrm{m})$ lateral alae originate at 340-800 $\mu \mathrm{m}$ posterior from lips and disappear before the posterior end of oesophagus. In the juvenile male, they originate just posterior to lips, are wider at their beginning and extend all along body. In cross-section, alal sclerotized supports nearly flat. Dorsal lip slightly wider than long, latero-ventral lips longer than wide. Lips lacking posterior lobes. Labial flanges triangular. Interlabia about half length of lips.
Labial pulp widening anteriorly; lobi rounded. Oesophagus $9.4-13.1 \%$ of body length. Ratio oesophagus/ventricular appendage 2.6-3.2. Ratio oesophagus/intestinal caecum 2.7-3. Intestinal caecum slightly longer than ventriculus plus appendage in the biggest female, and slightly shorter in the other specimens. Excretory pore slightly posterior to nerve ring. Tail with spined conical mucronate extremity.

Male : spicules slightly unequal, 5-7\% of body length. Preanal papillae 26-29 pairs, one large medioventral preanal papilla, postanal papillae eight pairs : five subventral with the fourth from cloaca doubled, one lateral and one small lateroventral (probably phasmids).

Female : vulva sligthly posterior to the anterior third of body. Thin shelled eggs $65 / 60 \mu \mathrm{m}$.

\section{Measurements}

Females : length 63, 42; oesophagus 6050, 3950; ventriculus : length 350,250 ; width 325,325 ; intestinal caecum 2250, 1350; ventricular appendage 1850, 1400; distance vulva-anterior extremity 22, 16; tail 400, 225.

Males : length 35, 16; oesophagus 3600, 2100; ventriculus : length 180,100; width 200,100; intestinal caecum 1200,725; ventricular appendage 1300 , 800; tail 150,115; left spicule 2350, 750; right spicule 2420, not visible.

\section{DISCUSSION}

These specimens are close to $H$. aduncum by their measurements and morphology, but the mature specimens differ by having very thin lateral alae originating far behind lips and not extending beyond posterior end of oesophagus. By alae originating behind the lips, the specimens are similar to $H$. auctum according to the description of Hartwich (1975), a species synonymised with $H$. aduncum by Punt (1941). H. auctum was recorded from Callionymus lyra by Baylis (1939); however, in this latter species lateral alae extend all along the body and originate nearer the base of the lips $(50 \mu \mathrm{m})$, and the number of postanal papillae is larger (eight pairs). Examination of more specimens from Callionymus lyra would be necessary to know if these differential characters are constant and so we prefer to designate the specimens as Hysterothylacium sp.

\section{Maricostula INCURVA (Rudolphi, 1819) Fig. 9G}

Material : 1 тм $\mathrm{n}^{\circ}$ MNHN 539 BC; host : Xiphias gladius L., 1758 (Xiphiidae); Hossegor (France); 5-101960 ; collection R.Ph. Dollfus.

This female corresponds to the description of Hysterothylacium incurvum given by Hartwich (1975). Bruce and Cannon (1989) placed this species in their new genus Maricostula. Lateral alae are pointed in 


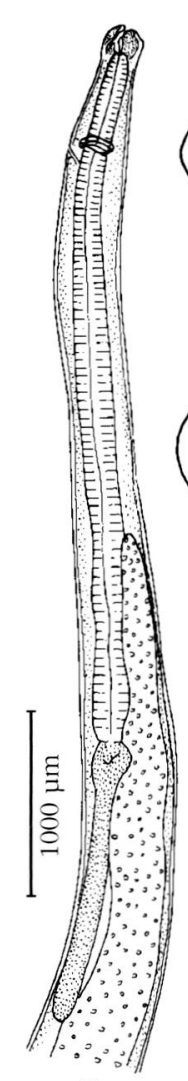

E
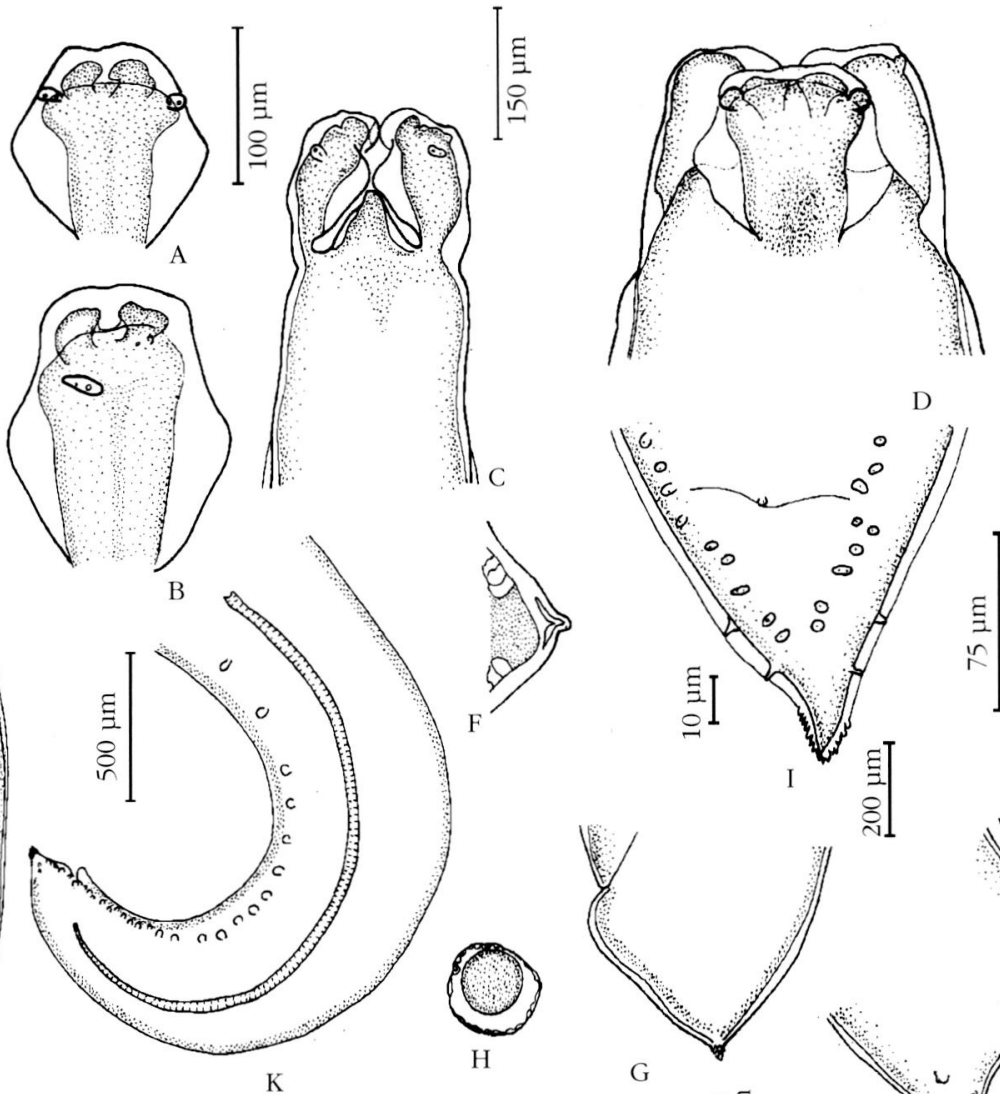

D

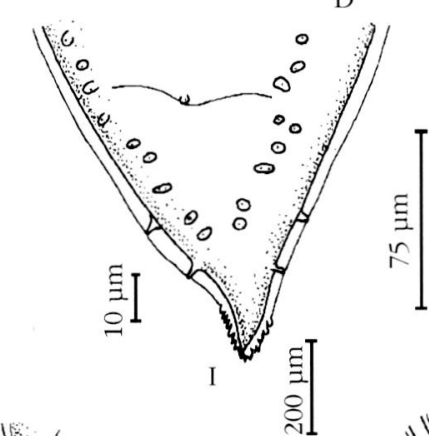

Fig. 8. - Hysterothylacium sp. A, female, dorsal lip; B, female, lateroventral lip; C, female, anterior end, ventral view; $\mathrm{D}$, juvenile male, anterior end, dorsal view; E, anterior part, lateral view; F, juvenile male, crosssection of lateral ala; G, female, posterior end; $\mathrm{H}$, egg; I, male, posterior end, ventral view; $\mathrm{J}$, male, posterior end, lateral view; K, male, posterior part, lateral view. Scale lines $(\mu \mathrm{m})$ : A,B,J, 100; C, 150; D,I, 75; E, 1000; F, 10; G, 200; H, 20; K, 500 .
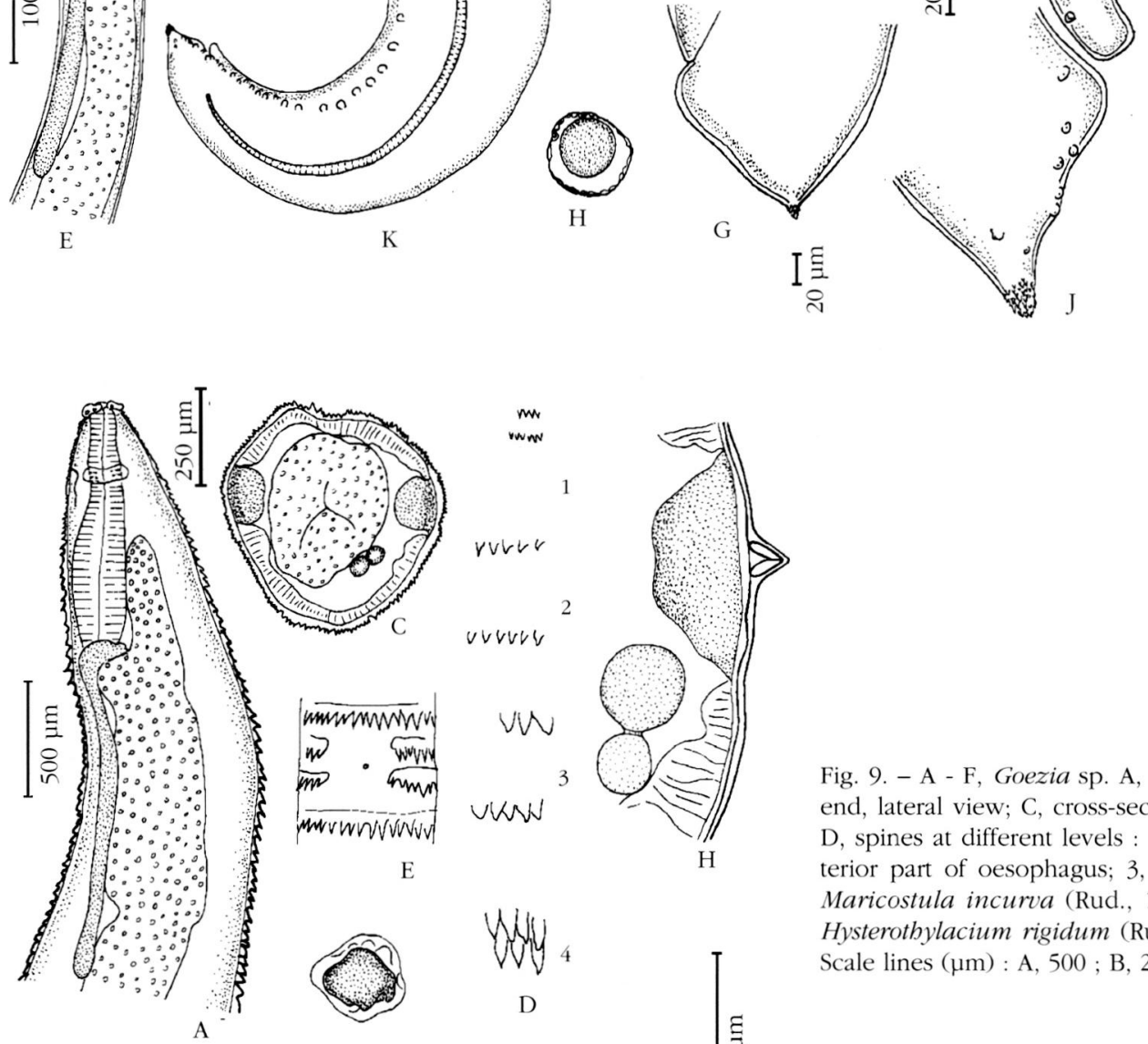

.

. 
cross-section as in the specimens from Mediterranean Sea studied by Petter and Maillard (1987). Deardorff and Overstreet (1981) identified as H. incurvum specimens from Florida with lateral alae bifurcated at the tips. Their material was collected from two hosts : Xiphias gladius and Tetrapterus albidus. Bruce and Cannon (1989) reexamined material of Deardorff and Overstreet from $T$. albidus and observed that it is not conspecific with $M$. incurva, differing by characters of the male caudal extremity and by narrower cervical alae. Alae bifurcated at the tip should be another character differentiating these parasites from $M$. incurva.

\section{GOEZIA SP. Fig. 9A-F}

Material : 1 o , 10 \% $\mathrm{n}^{\circ}$ MNHN 508 BC; host : Trisopterus luscus (L., 1758) (Gadidae); île d'Yeu (France); collected by J. Callot.

\section{DESCRIPTION}

Small nematodes with transverse rows of spines. Oesophagus short, small ventriculus wider than long $(80 / 150 \mu \mathrm{m})$; ventricular appendage thin, double, 1.32 times length of oesophagus; intestinal caecum thick, variable in length (ratio intestinal caecum/oesophagus $1 / 6-1 / 2$ ). Excretory pore slightly anterior to nerve ring. Deirids slightly posterior to nerve ring, surrounded by an area without spines. Tail short with a fingerlike terminal portion without spines, terminating in 5-6 small spikes. Transverse rows of spines begin just posterior to lips $(70 \mu \mathrm{m})$ from anterior extremity; spaces between rows $10 \mu \mathrm{m}$ in anterior part, $50 \mu \mathrm{m}$ in middle part and $16-20 \mu \mathrm{m}$ in posterior part; length of spines 3-6 $\mu \mathrm{m}$ in anterior part, 8-12 $\mu \mathrm{m}$ in middle part and $15-20 \mu \mathrm{m}$ in anal region; about 160 spines per row in the middle part of body.

Male : spines lacking dorsally from caudal extremity up to $350 \mu \mathrm{m}$. Spicules subequal. Gubernaculum lacking. The single male specimen being damaged, the number and disposition of papillae could not be determined.

Female : rows of spines interrupted laterally in the anal region. Vulva generally slightly posterior to middle of body. Rounded, thin shelled eggs $(40 \mu \mathrm{m}$ in diameter).

\section{DISCUSSION}

As the most important characters differentiating the species in the genus Goezia [number and disposition of anal papillae, see Deardorff and Overstreet (1980)] were not studied, specific identification was not performed.

Two species of Goezia were described in eastern North Atlantic and seas of North of Europe : Stefanski (1938) described G. sigalasi from Trachinus draco in the Atlantic; this species differs from the specimens described above by having unequal spicules; Punt (1941) identified as G. ascaroides a female parasite of Trachinus vipera in the North Sea; this identification, based only on females, is doubtful, as G. ascaroides was originally described from a freshwater fish, Silurus glanis.

\section{CONCLUSION}

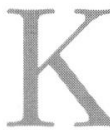
ey to the Ascarid species parasitizing Teleostean fishes from Eastern North Atlantic and Seas of the North of Europe :

1(6) Cuticule with transverse rows of spines

2(3) Male unknown

Goezia sp. (= G. ascaroides sensu Punt, 1941)

3(2) Male known

4(5) Spicules markedly unequal.

Goezia sigalasi Stefanski, 1938

5(4) Spicules subequal......Goezia sp. Petter (present paper)

6(1) Cuticule without transverse rows of spines

7(8) Male tail ending in a long tapering spike, without spines. Four pairs of single postanal and one pair of doubled adanal papillae. Intestinal caecum more than $2 / 3$ of oesophagus length. Lips with posterior lobes not extending as far as the posterior margins of interlabia. Parasites of Xiphias gladius .................Maricostula incurva (Rud., 1819)

8(7) Male tail ending in a short spike with or without spines. More than four pairs of postanal papillae. Intestinal caecum less than $2 / 3$ of oesophagus length

9(10) Lips with posterior lobes extending as far as the posterior margins of interlabia. Ventricular appendage longer than oesophagus. Parasites of Lophius piscatorius

Hysterothylacium rigidum (Rud.1809)

10(9) Lips lacking posterior lobes. Ventricular appendage shorter than oesophagus

11(12) 10 pairs or more than 10 pairs of postanal papillae. Caudal extremity lacking spines. Parasites of fishes belonging to the genus Thunnus.

Hysterothylacium cornutum (Stossich,1904)

12(11) Less than 10 pairs of postanal papillae. Caudal extremity with spines. Host specificity not restricted to one genus or one species

13(14) Lips constricted at mid-length. Interlabia measuring less than $1 / 4$ of lip length.

....Hysterothylacium reliquens (Norris and Overstreet, 1975)

14(13) Lips constricted at anterior third of lips. Interlabia measuring about half the lip length

15(18) Lateral alae originating far behind the base of lips

16(17) Lateral alae originating at about $50 \mu \mathrm{m}$ from base of lips and extending all along body.....

Hysterothylacium auctum (Rud., 1802)

(this species was synonymized with $H$. aduncum by Punt, 1941) 
17(16) Lateral alae originating at more than $300 \mu \mathrm{m}$ from base of lips and not extending beyond posterior end of oesophagus in mature worms....

Hysterothylacium sp. Petter (present paper)

18(15) Lateral alae originating from base of lips . Hysterothylacium aduncum (Rud.,1802)

19(20) Cervical alae very wide. Ratio oesophagus/maximal width of cervical alae $<54$. Ratio ventricular appendage/maximal width of cervical alae $<15$

H. aduncum gadi (O.F.Müller, 1776, species)

20(19) Cervical alae hardly wider than lateral alae. Ratio oesophagus/maximal width of cervical alae $>54$. Ratio ventricular appendage/maximal width of cervical alae $>15$

..H. aduncum aduncum (Rud., 1802, species)

These species have various geographical distributions. Three species or sub-species were recorded only in Eastern North Atlantic and seas of the North of Europe : Hysterothylacium auctum, H. aduncum gadi and Goezia sigalasi. Hysterothylacium reliquens is common to Eastern and Western Atlantic and Pacific. H. rigidum occurs like its host, Lophius piscatorius, in Mediterranean Sea and Eastern North Atlantic. The three other species have a widespread geographical distribution, two of them, Maricostula incurva and Hysterothylacium cornutum parasitizing only one genus or one host species, while the third one, $H$. aduncum aduncum was found in fishes of different orders.

\section{ACKNOWLEDGEMENTS}

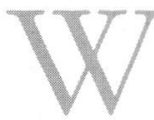

e are very grateful to Pr R.S. Bray for revising the english text.

\section{REFERENCES}

BAYlis H.A. Further records of Parasitic Worms from British Vertebrates. Annals and Magazine of Natural History, ser. 11, 1939, 4, 473-498.

Berland B. Nematodes from some Norwegian marine fishes. Sarsia, 1961, 1-50.

BRUCE N.L. \& CANNON L.R.G. Hysterotbylacium, Iheringascaris and Maricostula new genus, nematodes (Ascaridoidea) from Australian pelagic marine fishes. Journal of Natural History, 1989, 23, 1397-1441.

Dagnelie P. Analyse statistique à plusieurs variables. Les Presses Agronomiques de Gembloux, Gembloux, 1975 , $362 \mathrm{p}$.

Deardorff T.L. \& Overstreet R.M. Review of Hysterothylacium and Iheringascaris (both previously = Thynnascaris) (Nematoda : Anisakidae) from the Northern Gulf of Mexico. Proceedings of the Biological Society of Washington, 1980, 93, 1035-1079.

DeArdorfF T.L. \& Overstreet R.M. Hysterothylacium pelagicum sp. n. and H. cornutum (Stossich, 1904) (Nemato- da : Anisakidae) from marine fishes. Proceedings of the Helminthological Society of Washington, 1982, 49, 246251.

Dollfus R.P. Thynnascaris legendrei n. gen., n. sp., de l'estomac du germon, Germo alalonga (Gmel.). Bulletin de la Société Zoologique de France, 1933, 58, 7-13.

Dollfus R.P. Sur Contracaecum, Thynnascaris et Amphicaecum. Bulletin de la Société Zoologique de France, 1935, 60, 88-92.

Dollfus R.P. Aperçu général sur l'histoire naturelle des parasites animaux de la Morue atlanto-arctique Gadus callarias L. (= Morhua L.). Encyclopédie biologique, XLIII, Paris, 1953, 423 p

Fagerholm H.P. Nematode Length and Preservatives, with a Method for Determining the Length of Live Specimens. Journal of Parasitology, 1979, 65, 334-335.

Fagerholm H.P. Parasites of fish in Finland. VI. Nematodes. Acta Academiae Aboensis, Ser.B, 1982, 42, 1-128.

FAGERHOLM H.P. \& LÖVDAHL M. Induced morphometric variation in the preparation of nematode parasites for the LM and SEM. Systematic Parasitology, 1984, 6, 245-247.

Hartwinc G. Schlauchwürmer, Nemathelminthes, Rund- oder Fadenwürmer, Nematoda Parasitische Rundwürmer von Wirbeltieren. I. Rhabditida und Ascaridida. Die Tierwelt Deutschlands, Jena, Fischer Verlag,1975, 62, 256 p.

Müller O.F. Zoologiae danicae prodromus seu Animalium Daniae et Norvegiae indigenarum characteres, nomina et synonyma imprimis popularium. Copenhagen, 1776, $274 \mathrm{p}$.

Norris D.E. \& OverstreEt R.M. Thynnascaris reliquens sp. n. and T. habena (Linton, 1900) (Nematoda : Ascaridoidea) from fishes in the northern Gulf of Mexico and eastern U.S. seabord. Journal of Parasitology, 1975, 61, 330-336.

Petter A.J. Enquête sur les Nématodes des Poissons de la région nantaise. Identification des larves d'Ascarides parasitant les Sardines (en rapport avec les granulomes éosinophiles observés chez l'homme dans la région). Annales de Parasitologie Humaine et Comparée, 1969, 44, 559-579.

Petter A.J. \& Malllard C. Ascarides de Poissons de Méditerranée occidentale. Bulletin du Museum national d'Histoire naturelle, Paris, 4e série, section A, 1987, 9, 773-798.

Punt A. Recherches sur quelques Nématodes parasites de Poissons de la Mer du Nord. Mémoires du Musée Royal d'Histoire Naturelle de Belgique, 1941, 98, 110 p.

Rudolphi C.A. Fortsetzung der Beobachtungen über die Eingeweidewürmer Wiedem. Archiv für Zoologie und Zootomie (Braunschweig), 1802, 2, 1-67.

RudolphI C.A. Entozoorum, sive vermium intestinalium historia naturalis. vol. II, P. I, Amsterdam, 1809, 457 p.

STAT-ITCF1988 Manuel d'utilisation. Institut technique des Céréales et des Fourrages, Paris, 233 p.

STEFAnSKI W. Goezia sigalasi n. sp., parasite d'une "vive" (Trachinus draco). Livro Jubilar Prof. Travassos, Rio de Janeiro, Brasil III, 1938, 447-454.

Accepté le 27 janvier 1995 